\title{
I wouldn't mind moving actually: Exploring Student Mobility in Northern Ireland
}

\author{
David Cairns \\ CIES-IUL \\ Jim Smyth \\ Queen's University Belfast \\ Draft - citable version available at: \\ http://onlinelibrary.wiley.com/doi/10.1111/j.1468-2435.2009.00533.x/full
}

\begin{abstract}
This article examines orientations towards future geographical mobility amongst a sample of young people in Northern Ireland presently studying at third level educational institutions. Following contextualisation of youth mobility and immobility, particularly as pertaining to students, results of recent quantitative and qualitative research are presented. What is revealed is that over half of these young people, $55 \%$, see themselves living outside Northern Ireland at some point in the future. Furthermore, in response to a number of statements on family relationships, peer associations and community attachments, young people with intentions to live outside Northern Ireland in the future are not only more positively predisposed towards trans-national mobility but also have families who may support their migration intentions. These potentially mobile young people are also more likely to have peers and siblings with prior experience of geographical mobility and show signs of being less deeply attached to their local communities. A number of qualitative case studies are subsequently presented in order to illustrate the range of different mobility orientations within the sample, including both potential migrants and those more averse towards such movements.
\end{abstract}




\section{INTRODUCTION}

Young people are thought to be one of the most highly spatially mobile sections of the European population (King and Ruis-Gelices, 2003). Regarding why this is the case, prior studies on youth mobility emphasise the significance of geographical mobility as a resource for young people making education to work transitions and the importance of macro and micro structural factors in explaining migration decision-making (see, for example, Thomson and Taylor, 2005; Holdsworth, 2006).

In accounting for levels and patterns of youth mobility, explanations based on simple economic models, i.e. those using factors such as prosperity, wage levels or unemployment, do not seem to work effectively, since the "poorest" countries do not necessarily have the highest migration rates or the "richest" countries the lowest, at least in Europe (Hadler, 2006: 112-113). ${ }^{1}$ As Castles and Miller, note "No single cause is ever sufficient to explain why people decide to leave their country and settle in another" (1993: 22-24). We might equally argue that no single cause explains why people decide to stay in their country and not settle in another or why others prefer close proximity to long distance movements or short-term mobility to permanent migrations.

Specifically in relation to macro factors in youth mobility decision-making, regional and temporally specific labour and housing market conditions are 
certainly important to consider, alongside existing mobility patterns and directions of labour transfer systems (Hickey, 2002; Geisen, 2004). Regarding micro factors, family relationships, peer networks, community attachments and a need for personal fulfilment can all impact upon the mobility decision. At an intermediate level, we also need to consider prevailing social norms within a society, which help define what is considered "normal" or "acceptable" in respect to mobility behaviours.

A number of existing studies on youth and mobility (for example, King 2002; King and Ruis-Gelices, 2003; Baláž, and Williams 2004; Findlay et al., 2006) make the point that young people have been relatively neglected within both migration theory and historical accounts of population movements (see, for example, Cohen, 1995; Brettell and Hollifield, 2000; Pappastergiadis, 2000) and there is a particular need for work to be undertaken on long-term mobility. There would also appear to be a particularly lack of studies at ground level utilising qualitative approaches, as opposed to theorisations derived from demographic analysis (see Iredale, 1999, 2001; Peixoto, 2001a, 2001b).

This study also focuses exclusively upon student mobility. One reason for such an approach concerns the potential of such young people to be mobile, many students having "[...] more free time and opportunities and perhaps less responsibility than at any other time of their lives" (Hendry 
et al. 1993: 34). Hence, while they may have relatively small incomes by adult standards, as most do not have families of their own to care for or other major responsibilities such as paying a mortgage, a greater potential for mobility is present.

Existing studies on student mobility have largely concentrated upon short-term movements conducted within frameworks such as the European Union Socrates-Erasmus programme (see King and Ruis-Gelices, 2003; MoranoFoadi, 2005; Findlay et al., 2006), which while being of considerable value and interest in themselves, do not necessarily address the mobility decision-making process amongst more "mainstream" youth. ${ }^{2}$ The theme of youth and immobility is equally important: most young people do not migrate but rather stay in their countries of origins, perhaps not wanting to lose their accumulated locationspecific advantages (Hammar and Tamas, 1997; Fischer et al., 1997).

Regarding the location of the present research, there are a number of reasons why Northern Ireland presents an interesting case for a study of youth migration. With a small regional economy and a population of 1.6 million, Northern Ireland is somewhat peripheral to both the UK and the rest of the EU. The local economy has also undergone significant structural changes in the last quarter of a century, from being an economy based on shipbuilding, textiles and engineering to being heavily 
dependant on the public and service sectors for employment and growth, as is the case in many other similar sized regions in the EU. Attempts to replace traditional industries with high tech and knowledge based sectors have been less than totally successful in Northern Ireland (Smyth and Cebulla, 2008), leaving over $50 \%$ of local graduates employed in the public sector. Furthermore, the religious/sectarian conflict and divisions which have characterised social and political reality for so long have not lost their salience and are relevant to the question of migration patterns although the reality of social class divisions is beginning to assert itself in new ways.

MIGRATION IN NOTHERN IRELAND: HISTORICAL AND REGIONAL CONTEXT

The original research presented in this article seeks to explore student mobility in Northern Ireland specifically amongst young people studying at third level educational institutions in and around the Greater Belfast area. While limiting the scope of investigation to a particular educational universe and one specific region obviously negates the possibility of this study being representative of European youth or even the wider Northern Irish youth population, it is hoped that some insight into key mobility issues, in particular migration orientations, 
can be obtained from studying the accounts of a number of specific young people.

In respect to selecting Northern Ireland as the focus of this study, an important factor is the likelihood of capturing a broad spectrum of mobility orientations: young people with and without migration intentions; there would be little point in exploring migration orientations amongst a population were mobility is at an insignificant level. Prior research at a comparative European level has revealed that young people in Northern Ireland are more likely to consider migration than their counterparts in other Northern European states, including Germany, Denmark and the Netherlands, and as likely to be considering trans-national mobility as young people in former Eastern bloc countries such as Bulgaria (Biggart and Cairns, 2004). This is due, at least in part, to the aforementioned peripheral spatial position of Northern Ireland. This "isolation" may make geographical mobility more of a necessity than a choice due to the restricted range of work and study options available (Mac Laughlin 1997a: 147). Northern Ireland has also been at the forefront of social, economic and political change in Europe in recent years, including not only the on-going peace process and establishment of devolved local government but also a spiralling cost of living, particularly in relation to housing (Haurant, 2007; RICS, 2007). This study hence provides an opportunity to study how young people cope with additional 
challenges in entering labour and housing markets in one of Europe's more interesting societies.

In respect to the "Irish" migration context of these young people, since the midnineteenth century and well into the closing decades of the twentieth, emigration has been one of the defining features of Irish society. This fact is obvious from demographic trends alone. For instance, the population of Ireland as a whole declined from 8.1 million in 1841 to 5.1 million in 1993. Patterns of emigration have differed from region to region, with the bulk of migrants originating in the rural and poor west of Ireland. There have also been historical differences between the six counties which were to become Northern Ireland in 1922 and the rest of the country, which attained independence in the same year.

While the population of the twenty six counties which now constitute first what was known as the Free State and then the Republic of Ireland has declined from 6.5 million in 1841 to 3.5 million in 1993 , in the same period, the six counties of Northern Ireland actually showed a modest population growth, from 1.2 million in 1926 to 1.6 million in 1993. Therefore, while emigration from Northern Ireland existed during this period, it was of a considerably smaller magnitude compared to the rest of Ireland. Between 1951 and 1961 the annual average migration from Northern Ireland stood at 9,000 while the figure for the 
Republic of Ireland, with slightly more than double the population, was 40,800 (Hill, 2003: 797-798; Harris, 1990: 172). From the 1960s onwards, emigration from the Republic of Ireland began to decline and the population began to increase, albeit slowly.

Emigration was to return in Ireland during the 1980s although the figures for Northern Ireland showed no increase. Strong economic growth from 1990 onwards reversed the traditional pattern of outward migration from the Republic of Ireland as the country became a focus for inward migration from other EU member states and elsewhere and the population rose to 4.2 million in 2005 , and is projected to reach 5 million by 2021 (CSO, 2004). This contrasts with a historic low point of 2.8 million in 1961.

Migration from Northern Ireland, on the other hand, has historically been more stable and less subject to sudden fluctuations. In the two decades from 1960, the annual net migration varied between 6,000 and 8,000 a year, followed by a substantial rise during the early years of civil conflict in the 1970s. During the 1980s, migration declined (to 3,500 in 1985 , for instance) and began to rise again during the next decade to a current figure of 9,000 . Although Northern Ireland has the fastest growing population of any region in the UK, with projections showing an increase from 1.7 million in 2002 to 1.8 million in 2017, which would amount an increase of $5.4 \%$, this rate of population growth is 
significantly lower than that of the Republic of Ireland, were estimated growth is in the order of $25 \%$ by 2021 (CSO, 2004).

Calculating migration from Northern Ireland presents a number of difficulties. Migration through UK ports and airports is not differentiated meaning that outward migration from Northern Ireland to territories other than the UK cannot be easily extracted from overall figures. In addition, there is no administrative requirement to deregister on leaving Northern Ireland, nor is there any way of definitively charting migration by religious/sectarian membership or area. The method traditionally used by the Registrar General has been to calculate the figure from the transfer and issue of medical cards which are required to access medical care under the National Health Service. Although these figures can be adjusted for lag, persistent problems remain. People emigrating to countries outside the UK have little incentive to deregister and, indeed, might calculate that it would be to their advantage to remain registered in case they decide to return for medical reasons. Younger migrants, who make up the bulk of those leaving, also tend to be the healthiest population cohort and may not re-register for some time, if at all.

This method has been recently supplemented by questions in the Household Survey (Beatty, et al., 2006). Responses to these questions indicate that the main destination was Great Britain (approximately 50\%) with a further $20 \%$ to 
the Republic of Ireland and $30 \%$ elsewhere. These new calculations estimate migrant numbers at 9,000 for $2004 / 5$. This is, historically, at the high end of annual figures and would seem to indicate that either the numbers migrating have been underestimated or that, given the buoyant nature of the local economy and low unemployment figures, factors other than economic pressures are coming into play.

Estimating the number of graduates leaving Northern Ireland is somewhat less difficult. The Department of Education and Learning (DEL) collects extensive data on the education sector. Over the last number of years, a clear pattern has emerged. Students who study at the two local universities or institutes of higher education tend to remain in Northern Ireland after graduation. Some $90 \%$ of graduates, including postgraduates, take up employment locally with $5 \%$ going to Britain and 3\% to the Republic of Ireland. However, this is only part of the story as well over $25 \%$ of undergraduates study elsewhere in the UK and, significantly, these students tend to have the highest " $A$ " level results and better degree classifications than those students remaining in Northern Ireland (Purcell, 2005).

Of the graduate cohort of $2004-5$, out of those who gained a degree from a university in Britain more than half remained there, 56\%, with $4 \%$ taking up employment in the Republic of Ireland. This has led some commentators to talk 
of a "brain drain" of graduates from Northern Ireland - or more accurately a "brain distribution" and "brain redistribution" (Baláž et al., 2004: 4) - and indeed, in common with other UK regions, in Northern Ireland there is a net loss of graduates, mainly to the South East of England. As one recent study has commented:

The most highly qualified group of $\mathrm{NI}$ domiciled graduates were those who attended university outside of Northern Ireland and who were also not resident in Northern Ireland at the time of the survey (REF 84). The research focus of this paper is students who are currently at University in Northern Ireland but there is a clear need for further research into the significant group of students who choose to study elsewhere (Purcell, 2005: 81).

This group of students is not specifically studied in this article either, which focuses upon students currently undertaking a degree at the two universities in Northern Ireland. However, as mentioned by Purcell, further research into this already departed group, which may be interpreted in the broader context of the emergence of elite universities, mainly in the UK and the USA, which are plugged into a global network of multinational corporations which recruit from their graduates, is however needed in future studies.

The fact that a significant number of Northern Ireland students choose to study elsewhere in the UK has economic and social consequences for their region of origin, not to mention the more personal impact these dislocations have upon local families and communities. Within the UK, $5 \%$ 
of students in England and 6\% of Scottish students study outside their respective regions. In contrast, $\mathbf{2 8 \%}$ of students from Northern Ireland and a startling $38 \%$ from Wales study elsewhere in the UK. Of the Northern Irish students who go to university elsewhere in the UK, over $60 \%$ feel compelled or decide not to return. Those who study outside Northern Ireland tend to share common-socio economic characteristics, coming from the higher socio-economic backgrounds (the managerial and professional classes), are predominantly from the Protestant community and have higher entrance grades than those who remain. This group also tends to attain higher degree classifications (DEL, 2006).

\section{METHODOLOGY}

The original research upon which this article is based emanates from a project entitled "Culture, Youth and Future Life Orientations" (CYFLO). The aim of this project, conducted during 2005-2008, was to examine the future life orientations of highly-skilled young people, particularly in respect to geographical mobility and immobility. As mentioned previously, the original research cited in this article has been conducted in Northern Ireland, specifically in and around the Greater Belfast area, with both quantitative and qualitative methods utilised. Such an approach obviously means that there is no inclusion of young people 
who have already left and this limitation should be borne in mind in interpreting the results of this investigation.

In the quantitative research phase, a questionnaire was administered to a total of 250 young people, spread across four different academic disciplines in Northern Ireland's two universities, Queen's University Belfast and the University of Ulster, between October 2006 and February 2007, namely Arts and Humanities, Social Sciences, Science and Engineering. These disciplines were chosen in order to provide diversity and balance within the sample. The sample was also balanced in terms of gender and inclusion from ethnic minorities. A deliberate decision was however taken not to include students from courses wherein geographical mobility is mandatory as opposed to being a voluntary choice, such as languages. The questions themselves covered a range of topics, ranging from family and peer relationships to community attachments and future life plans.

For the qualitative part of this study, a total of 15 follow-up interviews were conducted with respondents sourced from the quantitative sample. These interviews were essentially semi-structured, consisting of initial questions regarding mobility orientations and experiences followed by more in-depth biographical discussion of individual-specific life events and plans, e.g. time spent working or studying abroad and future mobility intentions. The utility of the 
biographical approach to studying Irish youth migrations has been previously explored by Ní Laoire (2000) and shown to be particularly valuable in understanding the decision-making processes behind migrations (see also King and Ruiz-Gelices, 2003).

\section{QUANTITATIVE ANALYSIS}

The quantitative analysis which follows is based upon data gathered in the course of the CYFLO project. The results presented centre upon a number of key migration-related issues, namely the presence or absence of mobility intentions amongst the young people surveyed and their mobility decisionmaking processes. A number of descriptive statistics on mobility intentions are presented followed by more in-depth analysis using logistic regression.

Mobility Intentions

In respect to descriptive statistics, a number of breakdowns are presented on student mobility intentions amongst the young people surveyed, specifically their intentions to live outside Northern Ireland at some stage in the future; that these are measurements of intentions rather than actions already taken place should be considered when interpreting these results. The following 
breakdowns illustrate trends in mobility intentions in relation to gender, age, socio-economic background and academic background respectively.

\section{INSERT TABLE 1}

Table 1 illustrates that the majority of the young people surveyed (55\%) see themselves living outside Northern Ireland in the future, with slightly more males $(60 \%)$ than females $(51 \%)$ wishing to undertake trans-national mobility. This is a broad index, not linked to mobility towards a particular place or for a specified time period; these issues were explored via other questions on the questionnaire and by qualitative analysis. Putting this result into context, this trend of high mobility intentions represent a major contrast not only with the official statistics previously cited on present levels of student migrants, in the region of $10 \%$, but also with regionally comparable figures from the Eurobarometer 54.2 (2001) survey, wherein only $4 \%$ of those aged under 45 registered an intent to move outside of Northern Ireland in the next five years (cited in Hadler, 2006: 122). Admittedly, the age bracket is considerably broader, the timeframe of the Eurobarometer question is limited to mobility in the next five years and this figure of $4 \%$ refers to the general population rather than only university students, but the difference between the outcome of the present study and the Eurobarometer statistics is nevertheless striking. 
Regarding age, the age profile for the female respondents (mean age of 19.4 years) was slightly younger compared to their male counterparts (mean age of 20.5 years). Table 2 which follows illustrates the relationship between age and mobility intentions.

\section{INSERT TABLE 2}

While there are differences between age groups, the relationship between age and mobility intentions is unclear: the oldest age groups display the greatest proportions of potential leavers but we can also see that the level of migration intentions is almost equally high amongst the youngest respondents. Neither are the differences between these groups statistically significant according to the Pearson chi square figure. The relationship between the socio-economic backgrounds of these young people as derived from parental occupations and intentions to live outside Northern Ireland is explored in Table 3 which follows.

\section{INSERT TABLE 3}

As was the case with the relationship between age and mobility, these results are ostensibly inconclusive. Although the lowest levels of mobility intentions were to be found amongst young people from skilled and semi/unskilled manual backgrounds the proportion is still high, at $50 \%$ in each case. 
A further variable worth considering at this early stage of our analysis is the academic discipline of the respondents. As mentioned previously, the young people surveyed were clustered into four groups of equal size according to different disciplines: Arts and Humanities, Social Sciences, Science and Engineering. The relationship between intentions to live abroad and academic background is illustrated in Table 4.

\section{INSERT TABLE 4}

As we can see, there is some variation between the mobility orientations of these young people from various academic backgrounds, with slightly less than half of Social Sciences students considering mobility, around half of those studying Sciences and Engineering subjects also doing so, but a much greater proportion (68\%) of those studying Arts and Humanities subjects have intentions to live abroad. Further insight into the migration orientations of young people with particular educational credentials, including those studying Arts, is presented in the emblematic case studies included in the qualitative analysis.

While it would be useful to have some idea regarding the "typical" mobile or immobile young person, from these breakdowns we can see that it is not really possible to do so. While gender, age, socio-economic and educational differences are present between different groups, in no case did a statistically significant dichotomy emerge to demarcate those with mobility intentions and 
those without. It may therefore be the case that other factors such as family and peer relationships or community attachments have more of a bearing upon mobility decision-making than gender, age, social class or educational background. This is a finding consistent with conclusions from other studies of migration decision-making, were close relatives and friends have been shown to be influential.

\begin{abstract}
A migration decision is not an exclusive matter for the individual person. Migration acts are often conditioned by more of less imperative decisions of other family members or by the collective family. They can also be strongly affected by other families' decisions. The migration of close relatives or friends may demonstrate both chances and obstacles and sometimes the positive outcome of moving (Malmberg, 1997: 41).
\end{abstract}

Such an inconclusive outcome also invites more in-depth qualitative investigation of these young people's personal mobility orientations and subjective decision-making processes.

\title{
Mobility Decision-Making
}

Having found that more than half of those surveyed are considering undertaking trans-national mobility in the future, we now need to ask crucial questions about their geographical mobility decision-making processes. While making a move may be a personal choice, as mentioned previously, there may be other influences upon young people's choices, including family members, peers and 
prevailing social norms within local communities. The salience of these influences upon migration orientations is explored in the following presentation of results. In the three breakdowns which follow, the intention to be mobile is utilised as the dependent variable in a series of separate binary logistic regression analyses of responses made to various statements. Pearson chi square statistics have also been included as a measure of level of significance. In Table 5, responses are presented to a number of statements relating to various aspects of family culture. These statements range from subjective assessments of attachments to the family and the importance of family life to more factual statements on proximity to other family members, mobility amongst siblings and family support both to and from these young people.

\section{INSERT TABLE 5}

From Table 5, we can observe a general trend of those with mobility intentions being both more likely to have understanding families, e.g. being over twice as likely to agree with "My family would understand if I had to leave home to find a good job", and less likely to "feel incomplete" without their families, think that it is good to live with their parents or live close to most of their family members. Young people with mobility intentions are also significantly more likely to have siblings who have left home to live abroad, re-enforcing the impression that in the mobility decision-making process, families in Northern Ireland can act as an 
encouragement rather than an impediment to migration. There is an implication that these "mobility families" appreciate their offspring's need to be mobile, regardless of the strength or closeness of inter-generational relationships. This outcome is consistent with prevalent ideas in Ireland accepting migration as "natural" and "traditional" (Mac Laughlin, 1997b: 5).

\section{INSERT TABLE 6}

Regarding peer influences on mobility decision-making, Table 6 presents an overview of responses made to a series of statements on friendship networks. We can observe a number of interesting outcomes, for instance, those with mobility intentions were twice as likely to agree with "I have friends who live in other countries" and one and a half times more likely to have friends living in other parts of Northern Ireland, implying that there is a relationship between having mobile friends and wanting to be mobile oneself. On the more general statements on peer relationships, there are no major differences between those with and without mobility intentions, although the potential migrants do, perhaps realistically, anticipate having more transitional friendships, in being more prone to disagreeing with "I see myself having many of the same friends in the future as I have today". 
Before moving onto the discussion of results from the qualitative phase of this research, a number of indices relating to community attachments have also been analysed. This is perhaps a less well-defined area of investigation, but a number of exploratory issues have been included, relating to reactions to both abstract notions such as local and European identities and more concrete measures, for instance, involvement in social activities in one's community and broader civil participation.

\section{INSERT TABLE 7}

Table 7 reveals some extremely significant outcomes in terms of dichotomies between the potentially mobile and immobile: those who wish to leave Northern Ireland are more likely to feel European and dislike the areas they live in; they are also significantly more likely to consider having a relationship with someone even if it meant leaving Northern Ireland. The potentially mobile young people are also less likely to feel at home in Northern Ireland, to somewhat predictably want to leave their area, are less likely to socialise where they live and even go to church less frequently. All of these cited differences are significant according to the Pearson chi square statistics.

While the outcomes to these three different sets of statements are open to interpretation due to the subjectivity of young people's self-evaluations, e.g. 
what constitutes "feeling incomplete without your family" or being "at home in Northern Ireland" may differ greatly according to personal circumstances, we are beginning to obtain an idea regarding what differentiates mobile and immobile youth, specifically the potentially mobile have looser family attachments or families positively predisposed towards migration; they may be influenced by or follow their peers or siblings in their decision-making and have a much less profound attachment to Northern Ireland as a place and a greater association with Europe.

\section{QUALITATIVE ANALYSIS}

While a lack of space prevents discussion of all the qualitative interviews conducted, the following six case studies have been selected in order to provide further insight into the mobility and immobility orientations of the young people surveyed in Northern Ireland. The main intention is to illustrate how factors such as family and peer relationships, alongside community attachments, impact upon mobility orientations, not to mention other factors such as prior travel experiences and the need for personal development.

Gerard 
Aged 24, Gerard is in his third and final year of a degree in Civil Engineering at Queen's University, Belfast. At present, he is living at home with his parents, also in Belfast, although he has had the experience of living independently in previous years. Gerard has travelled widely in Europe and America, both for holidays and for sporting events, and has also had the experience of working in the USA, noting that as a result of this experience, "[...] you appreciate home more... become a different person".

In respect to this latter experience, Gerard appreciates the value of being mobile and compares his own situation favourably compared to those amongst his peers who have not had such experiences. His positive mobility experiences have also stimulated the desire for further travel, both in respect to employment and leisure. Gerard has an ambition to work in another European country in the future and to visit Australia for holidays. While such intentions may not amount to making Gerard a prospective "serial migrant" (Ossman, 2004), mobility has nevertheless been an important part of his educational trajectory to date and is likely to continue to be so in his future career; his family have also been generally supportive of his movements in the past and endorse his future travel plans. The fact that Gerald has been able to return to the family home in his final year of study would also indicate that he has a close relationship with his family, who appreciate the stresses and strains young people face in completing their education. 
Peter

Like Gerard, Peter, aged 21, is a Civil Engineering student at Queen's University, Belfast. At present, he is midway through the fourth year of a five year degree programme. Originally from Bangor in County Down, he now lives in a house shared with four friends in Belfast. Unlike Gerard however, Peter would seem to have a more distant relationship with his family or at least have antipathy towards the idea of living in the parental home. As he explains, in the first year of his degree he lived at home but "[...] that was no fun at all. So I moved out as soon as possible".

In respect to his travel experiences, besides visits to England, Scotland, the Channel Islands and the Republic of Ireland to visit friends and relatives, Peter has taken holidays to Spain, Portugal and France. Of further interest is the fact that Peter has experience of mobility in the past year connected to career development, specifically a work placement undertaken in Brazil. This placement was organised by IAESTE (International Association for the Exchange of Students for Technical Experience), an organisation dedicated to arranging foreign work placements for engineers. While Peter clearly enjoyed his Brazilian experience, he does note that his involvement in the Brazilian workplace was limited by an initial lack of fluency in Portuguese and not being 
accustomed to the local working culture. In fact, looking back on the experience now, Peter feels that "[...] it was pretty much a four month long holiday, in many respects".

Regarding his future, Peter is uncertain whether to pursue opportunities in Civil Engineering or try an alternative career path, specifically finance. Choosing this latter option may entail migration to the USA. In the forthcoming summer, he is planning to go to New York and test the water with an internship at Price Waterhouse Coopers: "I'm still not sure I want to go and be an engineer ... but whether I go into a finance job afterwards, I don't know. It's primarily to have a little taste". As such, while open to the idea of trans-national mobility, there is still a feeling from Peter that he would stay in Northern Ireland if it was possible.

\section{Simon}

Simon is an 18 year old Art and Design student at the University of Ulster in Belfast. He also lives in Belfast, in the west of the city, and works part-time in a supermarket. While content at present to continue living at home, Simon is considering a move out in the next year. As he explains, while his family are supportive and their home is "pretty comfortable", living with his parents is not Simon's preferred living situation: "I'd rather be out living with friends or 
whatever, like". He however feels that it is practical to move out yet since, "[...] its convenient...you know with money and that".

In respect to his future career, with opportunities in the Art field limited in Northern Ireland, Simon knows that moving is necessary if he wants to fulfil his ambitions, although his travel experiences to date have been restricted to family holidays in Europe. He has already considered England and the USA as his two most likely destinations, but would also regard Europe as a possibility: "I would prefer to live in other cities, like...London hopefully, like. Once I get my degree finished off". While he feels attached to where he lives now, Simon wouldn't let his ties to his family and friends stand in the way of realising his ambitions: "I wouldn't mind moving actually... if it would benefit me".

Janice

Like Simon, Janice is a first year Art and Design student at the University of Ulster in Belfast. Aged 19, she lives with her parents in Belfast. While there is a history of mobility in her family, her parents being migrants from China, Janice's own travel experiences are limited: "Ah no...I haven't really been travelling much...I would like to travel but I can't afford it". Like Simon, Janice realises that when she finishes her degree it may be necessary for her to make a move to another region of Ireland or the UK or elsewhere. 
I suppose that if I was given the opportunity...I would actually leave to go over to England, you know, if I had the opportunity to go, if I was given the opportunity to study in London or something like that...but for more convenience wise and money again, I have to stay here.

From her account it is however obvious that such a move would only be undertaken with great reluctance. From her responses to other questions, it is also clear that Janice enjoys a close relationship with her family in Northern Ireland and would not want risk breaking these ties. Therefore, if she had to move, it would only be to somewhere within close proximity and if the opportunity was presented to her rather than actively sought out by herself.

\section{Suzanne}

Suzanne is a 23 year old third year Sociology student at Queen's University, Belfast. At present, she lives with her parents in a suburb of the nearby city of Lisburn, County Antrim. This arrangement is, as she explains, largely for reasons of convenience and financial pragmatism, as she is presently dissatisfied with living at home and feels that it has a negative impact upon both her studies and her social life.

In respect to travel, Suzanne's experiences are largely confined to the leisure sphere only ever having been to Majorca on holidays, although when at primary 
school, she spent a summer in New York participating in a cross-community encounter scheme. In the future, Suzanne would also like to confine her future mobility to the leisure sphere and would be somewhat hesitant about living abroad on a more permanent basis.

I would like to go back to America again. You know, I went when I was about 10. And obviously I could do a lot more things now. l'd love to go to New York City....but I would actually really like to go to Australia. I've two friends who went to Australia for a year and I was jealous! I just want to experience, you know, kind of like a backpacking kind of holiday. I would really like to do that.

Regarding ideas about what to do after university, Suzanne is not sure what she would like to do: she feels that local opportunities are somewhat limited but is unsure of what is available elsewhere.

I don't know about living abroad. Well in Northern Ireland, I would be quite happy staying in Northern Ireland. Not particularly where I'm living now, but you know, in Northern Ireland somewhere. Even England. England wouldn't be too hard as I've got family over there. And you know, flights are quite cheap. My dad lives in England, so...it's not really a big deal. But if I had to you know, work, if my work entailed me to go abroad for a while, you know like I wouldn't be too annoyed about it, because, you know, you're getting to travel. It wouldn't be a big problem. But ideally, I would like to stay at least in the United Kingdom.

As with her choice of present living situation, we can see that Suzanne is driven by pragmatism, i.e. in respect to the direction of future mobility, her horizons are restricted to England, where she has both family connections and affordable flights. We can also observe that there is nothing particularly definitive about 
Suzanne's future mobility plans and while she is aware of the limited opportunities open to her in Northern Ireland, she is not sure about what is available elsewhere, even in England.

\section{Rachel}

Rachel is a 20 year old second year Sociology student, studying at Queen's University, Belfast. She lives at home with her parents approximately $30 \mathrm{~km}$ south of Belfast in the town of Ballynahinch, County Down. Regarding travel, while Rachel enjoys going on holiday, typically to Spain or other European destinations such as France, Holland and Germany, she has no plans for more long term mobility.

Two weeks is definitely long enough. By the end of it I'm always dying to get home so I can't see my going abroad for any long period of time. The furthest l'd probably go would be Scotland but that would only be if it was for a really good reason. I'd like to visit loads of other countries just to see them for a wee holiday but not for work or study.

In the future, Rachel sees herself remaining in Ballynahinch although not necessarily with her parents: "I obviously don't see myself in the same house". It is clearly very important for her to remain close to her friends and family. As she explains, "I like to stick to what I'm used to". 
Rachel's case illustrates the fact there are young people who have a preference to be immobile in their future life planning: they like living were they are and wish to stay there; immobility not only takes the form of being averse towards geographical mobility in future life planning but also in prolonged residence in the parental home. For such young people there is strong value in maintaining close family relationships and home-based friendship networks. ${ }^{3}$

\section{SUMMARY AND DISCUSSION}

European youth today face the challenge of successfully completing their education and entering the workforce in national and regional contexts characterised by prolonged educational trajectories and fragmented labour markets (Brannen et al., 2002; Leccardi, 2005; Walther, 2006; Furlong and Cartmel, 2007; Vinken, 2007). Within such a period of potential uncertainty, young people may not only be required to elongate their education to work transitions but also to be reflexive in their occupational decision-making if they are to successfully negotiate a path through education systems and into stable employment. For some young people, undertaking trans-national or interregional mobility may appear the best bet in respect to accessing and availing of educational and occupational opportunities; migration may even be a necessity within many highly-skilled professions (Ackers, 2005: 104; MoranoFoadi, 2005: 134). Others may think it better to stay closer to home, perhaps 
having the opportunity to fulfil their ambitions locally or feeling that ties to families, friends and local communities are too precious to risk breaking (see Hoerder, 2004). There may also be mobility hungry young people actively seeking a new challenge or adventure, who may choose to be mobile for reasons relating to personal development.

From the evidence presented in this article, we can observe how all of these different orientations towards mobility converge and conflict among a sample of young people from Belfast, thus providing us with some insight as to why some young people become mobile in their educational and occupational trajectories while others prefer to remain sedentary in their choices. The results of the quantitative analysis suggest that among the young people with plans to undertake mobility at some point in the future, constituting $55 \%$ of those surveyed, family and community attachments may be significantly weaker than amongst those planning to remain immobile. It is also possible that peers play a part in the mobility decision-making process. Although less prominent within the accounts of these young people, we should not neglect macro factors such as available job opportunities and ease of housing market entry. Young people such as Simon clearly have little chance of developing their careers if they stay in Northern Ireland while other older individuals such as Suzanne are finding their attempts to gain a foothold within the local housing market thwarted by rampant house price inflation. ${ }^{4}$ 
The cases of Gerard, Peter and Simon illustrate very different predispositions towards future life mobility: for Gerard, travel is experienced and anticipated very much in terms of personal development, constituting something of a "rite of passage" (Mac Laughlin 1997b: 6); for Peter, travel is very much associated with his career; for Simon, mobility is more of a necessity if he is to pursue his ambitions. Amongst those more averse to the idea of living outside Northern Ireland, we can see that Rachel restricts her travel horizons to the leisure arena, while Suzanne and Janice would like to do the same but feel that they may have to be mobile in their future careers irrespective of their own wishes. On this latter point, we can see that a relatively peripheral geographical position in respect to more central regions within a society or indeed from the rest of Europe places additional strains upon young people, which may lead to increased risk of social exclusion (see McVicar, 2001) and of having to make recourse to mobility in work and study trajectories even when such moves are not welcome by the young person in question.

Considering the present research context more specifically, we should play particular attention to the incongruity of there being a high level of migration intentions registered by the young people surveyed alongside what appear to be lower rates of actual migration from Northern Ireland, as represented in official statistics. In conclusion, we can suggest a number of explanations. 
Firstly, as implied in the discussion on the historical context of Irish migration, the reporting of official levels of youth migration may be inadequate, inaccurate or misleading, resulting in the true situation of youth mobility being hidden from the statisticians gaze. Secondly, what we are exploring in this article are geographical mobility orientations and intentions, not actual physical movements which have already taken place. It may well be that many young people do not translate their migration intentions and desires into reality, find their attempts thwarted or simply change their minds about leaving. Thirdly, as mentioned previously, the present sample is not representative of the broader youth population and may be presenting a particularly distorted view of mobility orientations in focusing upon a specific section of the youth population; however the current graduate migration rate of around $10 \%$ is still hugely below the $55 \%$ of young people registering mobility intentions in this study. Finally, we must consider the possibility that widespread youth migration is an emerging phenomenon which is only beginning to register in young people's biographical accounts and that official statistics are merely lagging behind what is actually happening on the ground. Out of all these conclusions, the latter is perhaps the most alarming considering the potential demographic and social impact of a major exodus upon local communities. Given the context in which this research took place, any such developments would have alarming sociopolitical consequences. 
Broadly speaking, recent statistics suggest that those who choose to remain in Northern Ireland to study have a significantly different profile to those who move elsewhere in the UK as outlined previously: students who stay in Northern Ireland tend to be from the minority Catholic community, come from the lower sections of the class structure and have lower entry grades and final degree classifications than their counterparts who relocate to Britain. After graduating, these tertiary education stayers also tend to be employed in jobs wherein they are not fully utilising their qualifications and are, on average, paid $20 \%$ less than comparative UK graduates (Prospects, 2006).

Politicians from those parties which represent the Protestant population have expressed concern at what they see as a "brain drain" of highly qualified students who go to Britain to study and then fail to return to Northern Ireland after graduation (UUP, 2005). Whatever the political motivation behind these concerns, the loss of highly qualified graduates is clearly a negative factor for companies assessing the viability of Northern Ireland for inward investment.

In respect to the future, recent changes to the funding of higher education in the UK may further reinforce divisions between those who go and those who stay. Current research indicates that the introduction of university 
fees and student loans is an important factor both in determining whether or not poorer students attend university and also their choice of university: the number of poorer respondents in a sample of English students choosing to live at home during their studies rose from $18 \%$ in 1998 to $56 \%$ in 2007 while those from social class A or B were much more likely to choose a place of study based on the reputation of the university and therefore were more likely to study at "top" universities (Davis, 2008).

As a similar system of student loans is in operation in Northern Ireland, one would expect a similar response from potential university students, a response which would be dictated by social class position rather than membership of one religious/sectarian community or another. The original research discussed in this article, taken together with the possibly high level of migration to Britain of Northern Ireland students and the impact of the fear of debt on poorer students, poses serious questions concerning the supply of young people sufficiently qualified to energize the transition of Northern Ireland from an industrial to a knowledge-based economy and reduce dependence on the service and public sectors.

\section{NOTES}

\footnotetext{
1 Hadler (2006) also provides an overview of "economic approaches" and "sociological approaches" in respect to intentions to migration within the European Union, although not specific to youth. For overviews of recent migration trends in Europe, see Stalker (2003), Krieger (2004) and Martí and Ródenas (2007).
} 


\begin{abstract}
2 Concerning broader perspectives on student mobility, it is also possible to view young people considering trans-national or inter-regional mobility as potential highly-skilled scientific migrants (HSM), bearing in mind the educational credentials they will hopefully attain in the near future (Koser and Salt, 1997; Salt, 1997; Ackers, 2005), who may become engaged in "brain drain" or "brain circulation" movements (Gaillard and Gaillard, 1997, 1998; Iredale 2001; Baláž et al. 2004).
\end{abstract}

3 Statistics illustrate the fact that the average home-leaving age for young people is rising, reaching well into their twenties (Cherlin et al., 1997; Bendit et al., 1999; Billari et al., 2001; Aassve et al., 2002). The theme of extended home-staying has been highlighted in numerous recent studies. In the UK, Holdsworth stresses not only the difficulties experienced by young people living at home in the face of social norms emphasising independent living but also the satisfactions expressed by those living at home gained through being able to maintain existing friendship networks and avoid 'the same sense of discontinuity with home compared to those who move away' (2006: 508). Much more research on this theme has been conducted in southern European contexts: recent studies in Spain, Portugal and Italy, illustrate how young people are able to maintain a high degree of independence without leaving the parental home (lacovou, 2001; Pappámikail, 2004; Holdsworth, 2005). Even when young people have the financial means to do so, they may not leave home and as part of a 'postponement syndrome' (Sgritta, 2001). Extended home-staying can hence be interpreted as a voluntary choice for such young people, who are 'not really interested in achieving independence from their parents' (Santoro, 2006: 149).

${ }^{4}$ Northern Ireland as a region has recently become the most expensive area within the UK outside of London in which to buy property, with the highest rises in house prices of any European region in 2006: conservative estimates put this rise at $44 \%$ compared to only $9-10 \%$ in the UK and 12\% in the Republic of Ireland (BBC 2007; RICS, 2007), while other sources claim that house prices soared by as much as $57.6 \%$ in 2006, which would make this the fastest rate of growth anywhere in the UK since lenders began records in 1973 (Haurant, 2007).

\title{
REFERENCES
}

Ackers, L.

2005 "Moving People and Knowledge: Scientific Mobility in the European Union", International Migration 43(5): 99-129.

Aassve, A. et al.

2002 "Leaving Home: a Comparative Analysis of ECHP Data", Journal of European Social Policy 12(4): 259-275.

Baláž, V., and Williams, A. 
2004 "'Been There Done That:' International Student Migration and Human Capital Transfers from the UK to Slovakia", Population, Place and Space 10: 217-237.

Baláž, et al.

2004 "Temporary versus Permanent Youth Brain Drain: Economic Implications", International Migration 42(4): 3-34. BBC

2007 "Home buyers face worst conditions",

http://news.bbc.co.uk/2/hi/uk_news/northern_ireland/6249189.stm

Beatty, R. et al.

2006 Long Term International Migration Estimates from Northern Ireland (2004-

5): Sources and Methodology, Belfast: NISRA.

Bendit, R. et al. (eds)

1999 Youth and Housing in Germany and the European Union. Data Trends on

Housing: Biographical, Social and Political Aspects, Opladen: Leske and Budrich.

Biggart, A. and Cairns, D.

2004 Families and Transitions in Europe: Comparative Report, Coleraine: University of Ulster.

Billari, F. C., et al.

2001 "Leaving Home in Europe: The Experience of Cohorts Born Around 1960", International Journal of Population Geography 7(5): 339-356.

Brannen, J. et al. (eds)

2002 Young Europeans, Work and Family. Futures in Transition, London:

Routledge.

Brettell, C. B. and Hollifield, J. F. (eds)

2000 Migration Theory: Talking Across Disciplines, London: Routledge.

Buckley, M.

1997 "Sitting on Your Politics. The Irish Among the British and Women Among

the Irish" in J. Mac Laughlin (ed.) Location and Dislocation in Contemporary

Irish Society. Emigration and Irish Identities. Cork: Cork University Press.

Castles, S. and Miller, M. J.

1993 The Age of Migration: International Population Movements in the Modern

World, Houndmills: Macmillan.

Cherlin, A. J. et al.

1997 "Still in the Nest: Delayed Home Leaving in Europe and the United

States", Journal of Family Issues 18(6): 572-575.

Cohen, R. (ed.)

1995 The Cambridge Survey of World Migration, Cambridge: University Press.

CSO

Davies, P. et al.

2008 Knowing Where to study? Fees, Bursaries and Fair Access, Staffordshire:

The Sutton Trust and Staffordshire University. 
DEL (Department of Education and Learning)

2006 Statistical Bulletin (August), Destination of leavers from Higher Education: Northern Ireland 2004/5, Belfast: DEL

2006 Population and Labour Force Projections (Ireland), 2006-2036, Dublin: Stationery Office.

Findlay, A. et al.

2006 "Ever Reluctant Europeans. The Changing Geographies of UK Students

Studying and Working Abroad", European Societies 13(2): 291-318.

Fischer, P. et al.

1997 "Should I Stay or Should I Go" in T. Hammar, et al. (eds) International

Migration, Immobility and Development. Multidisciplinary Perspectives,

Oxford: Berg.

Furlong, A. and Cartmel, F.

2007 Young People and Social Change. Second Edition, Buckingham: Open University Press.

Gaillard, J. and Gaillard, A. M.

1997 "The International Mobility of Brains: Exodus or Circulation?", Science, Technology \& Society 2(2): 195-228.

Gaillard, J. and Gaillard, A. M.

1998 "The International Circulation of Scientists and Technologists: A Win-lose

or Win-Win situation?", Science Communication 20(1): 106-115.

Geisen, T.

2004 "Migrants in 'Labor Transfer Systems"' in T. Geisen, et al. (eds) Migration,

Mobility and Borders. Issues of Theory and Policy. Frankfurt: IKO.

Hadler, M.

2006 "Intentions to Migrate Within the European Union: A Challenge for Simple

Economic Macro-Level Explanations", European Societies 8(1): 111-140.

Hammar, T. and Tamas, K.

1997 "Why do People Go or Stay?" in T. Hammar, et al. (eds) International

Migration, Immobility and Development. Multidisciplinary Perspectives,

Oxford: Berg.

Harris, R. et al.

1990 The Northern Ireland Economy, London: Longman.

Haurant, S.

2007 "Northern Ireland tops UK house price inflation" in The Guardian (4 April 2007), http://www.guardian.co.uk/

Hendry, L. B., et al.

1993 Young People's Leisure and Lifestyles, London, Routledge.

Hickey, A. A.

2002 "Community Attachment and Migration" in T. Geisen (ed.) Mobilität und

Mentalitäten. Frankfurt: IKO.

Hoerder, D. 
2004 "Migration as a Balancing Process: Individuality and Societal Connections of Mobility" in T. Geisen et al. (eds) Migration, Mobility and Borders. Issues of Theory and Policy Frankfurt: IKO.

Holdsworth, C.

2005 "'When are the Children going to Leave Home'! Family Culture and Delayed Transitions in Spain", European Societies 7(4): 547-566. Holdsworth, C.

2006 '"Don't You Think You're Missing Out, Living at Home?' Student Experiences and Residential Transitions", The Sociological Review 54(3): 495-519.

lacovou, M.

2001 "Leaving Home in the European Union" in Working Papers of the Institute for Social and Economic Research, paper 2001-18. Colchester: University of Essex.

Iredale, R.

1999 "The Need to Import Skilled Personnel: Factors Favouring and hindering

its International Mobility", International Migration 37(1): 89-111. Iredale, R.

2001 "The Migration of Professionals: Theories and Typologies", International Migration 39(1): 7-24.

Kelly, K. and Nic Giolla Choille, T.

1990 Emigration Matters for Women, Dublin: Attic Press.

King, R.

2002 "Towards a new map of European migration", International Journal of Population Geography 8: 89-106.

King, R., and E. Ruiz-Gelices

2003 "International student migration and the European year abroad: effects on

European identity and subsequent migration behaviour", International Journal of Population Geography 9: 229-252.

Koser, K. and Salt, J.

1997 "The geography of highly skilled international migration", International Journal of Population Geography 3: 285-303.

Krieger, $\mathrm{H}$.

2004 Quality of Life in Europe. Migration Trends in an Enlarged Europe, Luxembourg: Office for Official Publications of the European Communities.

Mac Laughlin, J.

1997a "Social Characteristics of 'New Wave' Irish Emigration" in J. Mac Laughlin (ed.) Location and Dislocation in Contemporary Irish Society. Emigration and Irish Identities. Cork: Cork University Press.

Mac Laughlin, J.

1997b "Emigration and the Construction of Nationalist Hegemony in Ireland.

The Historical Background to 'New Wave' Irish Emigration" in J. Mac 
Laughlin (ed.) Location and Dislocation in Contemporary Irish Society. Emigration and Irish Identities. Cork: Cork University Press.

Malmberg, G.

1997 "Time and Space in International Migration" in T. Hammar, et al (eds) International Migration, Immobility and Development. Multidisciplinary Perspectives, Oxford: Berg.

Martí, M. and Ródenas, C.

2007 "Migration Estimation Based on the Labour Force Survey: An EU-15 Perspective", International Migration Review 41(1): 101-126.

McVicar, D.

2001 Young People and Social Exclusion in Northern Ireland, Belfast: University of Ulster/Northern Ireland Economic Research Centre/Department of Higher and Further Education, Training and Employment.

Morano-Foadi, S.

2005 "Scientific Mobility, Career Progression, and Excellence in the European Research Area", International Migration 43(5): 134-160.

Ní Laoire, C.

2000 "Conceptualising Irish Rural Youth Migration: A Biographical Approach", International Journal of Population Geography 6: 229-243.

Ossman, S.

2004 "Studies in Serial Migration", International Migration 42(4): 112-121.

Pappámikail, L.

2004 "Intergenerational Relationships, Family Support and the Transition of Young People to Adult Life in Portugal", Sociologia: Problemas e Prácticas 46: 91-116.

Pappastergiadis, N.

2000 The Turbulence of Migration, Cambridge: Polity.

Peixoto, J.

2001a "The international mobility of highly skilled workers in transitional corporations: the macro and micro factors of the organizational migration cadres", International Migration Review 35(4): 1030-1053.

Peixoto, J.

2001b "Migration and Policies in the European Union: Highly Skilled Mobility, Free Movement of Labour and Recognition of Diplomas", International Migration 39(1): 33-59.

Prospects,

Destinations of graduates from Northern Ireland, London: HECSU.

Purcell, K, et al.

2005 Northern Ireland's Graduates: The Classes of '95 and '99, Belfast: DEL.

Royal Institution of Chartered Surveyors

2007 European Housing Review 2007, London: RICS.

Salt, J. 
1997 "International movement of the highly skilled", OECD Occasional Paper no. 3, Paris: International Migration Unit, OECD.

Santoro, M.

2006 "Living with Parents. A Research Study on Italian Young People and their Mothers" in C. Leccardi and E. Ruspini (eds) A New Youth? Young People, Generations and Family Life, Ashgate: Aldershot.

Sexton, J.

2003 "Emigration and Immigration in the Twentieth Century: An Overview" in J.

P Hill (ed.) A New History of Ireland, Oxford: OUP.

Sgritta, G.

2001 "Family and Welfare Systems in the Transition to Adulthood: An

Emblematic Case Study" in Working Papers of the Institute for Social and

Economic Research, paper 2001-18, Colchester: University of Essex.

Shuttleworth, I.

2007 "Graduate Emigrants. A 'New Wave' in Irish Emigration?" in J. Mac Laughlin (ed.) Location and Dislocation in Contemporary Irish Society.

Emigration and Irish Identities. Cork: Cork University Press.

Smyth, J, and Cebulla, A.

2008, The Glacier Moves: Economic Change and Class Structure in Northern

Ireland in C. Coulter and M. Murray, Northern Ireland after the Troubles: S

Society in Transition, Manchester, Manchester University Press.

Stalker, P.

2002 "Migration Trends and Migration Policy in Europe", International Migration, 40(5): 151-179.

Thomson, R. and Taylor, R.

2005 "Between cosmopolitanism and the locals: Mobility as a resource in the transition to adulthood", Young 13(4): 327-342.

UUP (Ulster Unionist Party)

2005 (December) Losing Our Talent, The UUP Plan for tackling Northern Ireland's Brain Drain, Belfast, Press release, UUP.

Walther, A.

2006 "Regimes of youth transitions. Choice, flexibility and security in young people's experiences across different European contexts", Young 14(2): 119-139.

Williams, A. M. et al.

2004 "International Labour Mobility and Uneven Regional Development in Europe. Human Capital, Knowledge and Entrepreneurship", European Urban and Regional Studies 11(1): 27-46. 
TABLE 1

INTENTIONS TO LIVE OUTSIDE NORTHERN IRELAND BY GENDER

\begin{tabular}{|l|c|c|c|}
\hline \multirow{2}{*}{ Gender } & \multicolumn{3}{|c|}{ Live Outside Northern Ireland (\%) } \\
\cline { 2 - 4 } & Yes & No & Total \\
\hline \multirow{3}{*}{ Male } & 60 & 40 & 100 \\
Female & 51 & 49 & 100 \\
All $(\mathrm{N}=247)$ & 55 & 45 & 100 \\
\hline
\end{tabular}

Note: Pearson Chi Square $=.173$

Source: CYFLO 2007

TABLE 2

INTENTIONS TO LIVE OUTSIDE NORTHERN IRELAND BY AGE

\begin{tabular}{|l|c|c|c|}
\hline \multirow{2}{*}{ Age } & \multicolumn{3}{|c|}{ Live Outside Northern Ireland (\%) } \\
\cline { 2 - 4 } & Yes & No & Total \\
\hline \multirow{3}{*}{$18-19$} & 59 & 41 & 100 \\
$20-21$ & 44 & 56 & 100 \\
$22-23$ & 61 & 29 & 100 \\
$>=24$ & 67 & 33 & 100 \\
All $(\mathrm{N}=247)$ & 55 & 45 & 100 \\
\hline
\end{tabular}

Notes: Pearson Chi Square $=.114$ 
Source: CYFLO 2007

TABLE 3

INTENTIONS TO LIVE OUTSIDE NORTHERN IRELAND BY SOCIOECONOMIC BACKGROUND

\begin{tabular}{|l|c|c|c|}
\hline \multirow{2}{*}{ Socio-Economic Background } & \multicolumn{3}{|c|}{ Live Outside Northern Ireland (\%) } \\
\cline { 2 - 4 } & Yes & No & Total \\
\hline Skilled Non-Manual & 54 & 46 & 100 \\
Skilled Manual & 50 & 50 & 100 \\
Semi/Unskilled Non-Manual & 69 & 31 & 100 \\
Semi/Unskilled Manual & 50 & 50 & 100 \\
Service & 60 & 30 & 100 \\
N/A & 60 & 40 & 100 \\
All (N=234) & 55 & 45 & 100 \\
\hline
\end{tabular}

Notes: Pearson Chi Square $=.720$

Source: CYFLO 2007

TABLE 4

INTENTIONS TO LIVE OUTSIDE NORTHERN IRELAND BY ACADEMIC DISCIPLINE

\begin{tabular}{|l|c|c|c|}
\hline \multirow{2}{*}{ Type of Course } & \multicolumn{3}{|c|}{ Live Outside Northern Ireland (\%) } \\
\cline { 2 - 4 } & Yes & No & Total \\
\hline & & & 100 \\
Social Sciences & 46 & 54 & 100 \\
Sciences & 52 & 48 & 100 \\
Engineering & 53 & 47 & 100 \\
Arts \& Humanities & 68 & 32 & 100 \\
All (N=247) & 55 & 45 & \\
\hline
\end{tabular}


Note: Pearson Chi Square $=.092$

Source: CYFLO 2007

TABLE 5

STATEMENTS RELATING TO FAMILY BY INTENTIONS TO BE MOBILE

\begin{tabular}{|c|c|c|c|}
\hline Statement & $B$ & $\operatorname{Exp}(B)$ & Chi Square \\
\hline $\begin{array}{l}\text { My family would understand if I had } \\
\text { to leave home to find a good job }\end{array}$ & .773 & 2.167 & 217 \\
\hline $\begin{array}{l}\text { I have siblings who left home to live } \\
\text { in other countries }\end{array}$ & .662 & 1.938 & .037 \\
\hline $\begin{array}{l}\text { I have siblings who left home to live } \\
\text { in other parts of Northern Ireland }\end{array}$ & .205 & 1.228 & .489 \\
\hline $\begin{array}{l}\text { My family need me to support them } \\
\text { I need my family to support me }\end{array}$ & $\begin{array}{l}.138 \\
-.156\end{array}$ & $\begin{array}{l}1.148 \\
.855\end{array}$ & $\begin{array}{l}.693 \\
.543\end{array}$ \\
\hline $\begin{array}{l}\text { Having a good family life is more } \\
\text { important than having a good job }\end{array}$ & -.466 & .628 & .237 \\
\hline Most of my family live near me & -.696 & .498 & .022 \\
\hline $\begin{array}{l}\text { It's good to live at home with your } \\
\text { parents }\end{array}$ & -1.017 & .368 & .000 \\
\hline $\begin{array}{l}\text { I would feel incomplete without my } \\
\text { family }\end{array}$ & -1.282 & .278 & .032 \\
\hline
\end{tabular}

Source: CYFLO 2007 
TABLE 6

STATEMENTS RELATING TO PEERS BY INTENTIONS TO BE MOBILE

\begin{tabular}{|c|c|c|c|}
\hline Statement & $B$ & $\operatorname{Exp}(B)$ & Chi Square \\
\hline I have friends who live in other countries & .737 & 2.091 & .008 \\
\hline $\begin{array}{l}\text { I have friends who live other parts of } \\
\text { Northern Ireland }\end{array}$ & 354 & 1.424 & 339 \\
\hline $\begin{array}{l}\text { Having good friends is more important } \\
\text { than having a good job }\end{array}$ & .078 & 1.081 & .797 \\
\hline $\begin{array}{l}\text { My friends would understand if I went to } \\
\text { live in another country }\end{array}$ & .072 & 1.075 & .880 \\
\hline I would feel incomplete without my friends & -.048 & .954 & .908 \\
\hline $\begin{array}{l}\text { I have many of the same friends today as } \\
\text { I did when I was a child }\end{array}$ & -.059 & .943 & 819 \\
\hline $\begin{array}{l}\text { My friends would understand if I went to } \\
\text { live in another part of Northern Ireland }\end{array}$ & -.123 & .884 & .825 \\
\hline Most of my friends live near me & -.256 & .775 & .174 \\
\hline $\begin{array}{l}\text { I see myself having many of the same } \\
\text { friends in the future as I have today }\end{array}$ & -.531 & .588 & .134 \\
\hline
\end{tabular}

Source: CYFLO 2007 
TABLE 7

STATEMENTS RELATING TO COMMUNITY ATTACHMENTS BY

INTENTIONS TO BE MOBILE

\begin{tabular}{|l|c|c|c|}
\hline Statement & $B$ & Exp (B) & Chi Square \\
\hline I feel more European than Northern Irish & 1.022 & 2.780 & .010 \\
I don't like the area I live in & .738 & 2.092 & .027 \\
I can name all the countries in the & .335 & 1.398 & .300 \\
European Union & & & \\
I know how many countries there are in & .178 & 1.195 & .519 \\
the European Union & & & \\
I think of myself first and foremost as an & -.024 & .976 & .935 \\
individual & & & \\
I support my local football team & -.114 & .892 & .692 \\
I always vote in elections & -.182 & .834 & .485 \\
I regularly go to church & -.529 & .589 & .042 \\
I regularly socialise in my own area & -.787 & .455 & .004 \\
I would not consider having a & -1.116 & .328 & .000 \\
relationship with someone from another & & & \\
country if it meant having to leave & & & \\
Northern Ireland & -1.517 & .219 & .000 \\
I always want to live in my area & -2.565 & .077 & .000 \\
\hline I feel at home in Northern Ireland & &
\end{tabular}

Source: CYFLO 2007 